\title{
The social side of school: Why teachers need social psychology
}

\section{Citation}

Gehlbach, Hunter. 2010. The social side of school: Why teachers need social psychology.

Educational Psychology Review 22, no. 3: 349-362.

\section{Published Version}

doi:10.1007/s10648-010-9138-3

\section{Permanent link}

http://nrs.harvard.edu/urn-3:HUL.InstRepos:4460862

\section{Terms of Use}

This article was downloaded from Harvard University's DASH repository, and is made available under the terms and conditions applicable to Other Posted Material, as set forth at http:// nrs.harvard.edu/urn-3:HUL.InstRepos:dash.current.terms-of-use\#LAA

\section{Share Your Story}

The Harvard community has made this article openly available.

Please share how this access benefits you. Submit a story.

Accessibility 
Running head: THE SOCIAL SIDE OF SCHOOL

The social side of school: Why teachers need social psychology

\begin{abstract}
Teaching and learning are fundamentally social enterprises. In attempting to understand, explain, and predict social behavior, social psychologists have amassed scores of empirically-grounded, fundamental principles. Yet, many such principles have yet to be applied to classrooms despite the social nature of these settings. This article illustrates how infusing novel concepts from social psychology into teachers’ repertoires holds untapped potential to improve their pedagogy, ability to motivate students, and capacity to enrich students' understanding of subject matter. This article first examines three domains of social psychology - social cognition, influence/persuasion, and interpersonal relations - and illustrates how applications of principles from each domain could benefit classrooms. Next, two exemplars are presented to demonstrate the efficacy of past interventions that are rooted in social psychological principles. Finally, pathways through which teacher educators can introduce new social psychological concepts and applications to teachers are explored.
\end{abstract}


Running head: THE SOCIAL SIDE OF SCHOOL

As currently practiced in most schools, learning and teaching are fundamentally social acts (Goodenow, 1992). Students learn by interacting with their teacher and through working with one another. Even when students read or interact with inanimate objects such as an abacus or vial of solution, much of their potential learning remains unrealized until a social interaction occurs. In these instances, the interpretation of the experience often facilitates learning when a teacher or fellow student explains what has happened, what is happening, what should happen next... or, in the case of my own math and chemistry experiences, what should have happened.

Teachers’ roles in the classroom are equally social. Explaining concepts, keeping students on task, and communicating with fellow faculty members and parents are obviously social. Although less obvious, planning classes and grading papers are anticipatory social acts in that these activities require teachers to forecast how students will react to lesson plans and comments, respectively. Even monitoring a study hall includes exchanges of gestures and facial expressions, setting up seating arrangements, and developing community norms that affect the social experience for everyone involved.

Given the fundamentally social nature of learning and teaching, greater knowledge of core concepts that elucidate complex social dynamics and guide ensuing behavior would be a tremendous boon for teachers. The discipline of social psychology has great untapped potential to help teachers understand and manage many of these social aspects of the classroom. Although some concepts from this discipline (e.g., selfefficacy, stereotype threat, etc.) are already known in education circles, many are not. Realizing the potential of these lesser-known concepts will pay off in three important 
Running head: THE SOCIAL SIDE OF SCHOOL

ways. First, because social processes are fundamental to so many aspects of learning and teaching, intervening at this level often produces multiple desirable outcomes (i.e., one intervention might have an array of benefits). Furthermore, by drawing on fundamental principles, applications of these ideas may be generalized across many facets of teachers' jobs (i.e., one principle may have multiple applications). Second, the effects of interventions that successfully modify basic social processes can be disproportionately large. In other words, by changing social processes that occur repeatedly, small interventions can have big effects. Third, because social processes often set cycles in motion, interventions that establish positive patterns of interaction can be long lasting.

This article focuses on the benefits of increasing educators' - particularly teachers' - knowledge of the social side of school. However, it is important to simultaneously weigh the costs of ignoring this side of schooling. Achievement gaps, dropping out, and school safety provide illustrative examples - although the costs impact students across many more domains. First, with respect to achievement gaps, ignoring the social aspects of school seems likely to reify discrepancies between racial groups. Teachers who fail to de-bias their perceptions and expectations of students are likely to foster differential achievement outcomes for students of different races (Ferguson, 2003; Rosenthal, 1991). As the student population in this country diversifies and education becomes more and more important in the workforce, attention to this issue becomes increasingly urgent. Second, students who experience a diminished sense of belonging at school are less likely to remain motivated and engaged in school; consequently, they are more likely to drop out (Fine, 1991; Juvonen, 2006). Attention to this issue is similarly 
Running head: THE SOCIAL SIDE OF SCHOOL

urgent given that Latinos, the largest and fastest growing minority group in the country, are dropping out of school at a rate of over 20\% (National Center for Educational Statistics, 2009). Third, ignoring social facets of school has troubling implications for school safety. From school shootings, to bullying (and “cyber-bullying”), to psychological safety it is clear that the social climate in schools has a tremendous impact on the extent to which students feel safe (E. Aronson, 2000b; Juvonen, 2007; Olweus, Fry, Bjoerkqvist, \& et al., 1997). As Reynolds et al. (2008) emphasize, students must feel safe before learning can occur. Furthermore, the complex mechanisms underlying the problems of achievement, dropping out, and safety can easily feed off of one another to form destructive cycles. In sum, although this article focuses on anticipated benefits of social psychology, ignoring the social side of school carries grave costs for students’ motivation, achievement, and psychological well-being.

Rather than documenting those contributions from social psychology that have gained traction in education, this article looks forward to identify domains in which novel social psychological concepts could be applied to education but have not yet been translated widely into practice. Three guiding questions focus this goal. First, I explore: What might social psychology do for teachers? I provide three examples of the types of social psychological concepts that could contribute to education but that are rarely employed currently. Next, by describing two instances when social psychological ideas have been implemented in classroom settings, I examine: How effective have social psychological interventions been in the past? In the final section - How might these 
Running head: THE SOCIAL SIDE OF SCHOOL

potential contributions of social psychology be realized? - I consider different avenues through which social psychology might be infused into teachers’ repertoires.

\section{What might Social Psychology do for Teachers?}

Before exploring this first question, a basic definition of social psychology is needed. This task is deceptively challenging. As Elliot Aronson notes, "There are almost as many definitions of social psychology as there are social psychologists” (p. 5, 1999). Some scholars focus on how people think about themselves and others (e.g., Fiske \& Taylor, 1991), others on influence and persuasion (e.g., Cialdini, 2009), and others on interpersonal and inter-group relations (e.g., Devine, 1995). In thinking about social psychology’s potential to improve schooling, Myers’ definition, “Social psychology is the scientific study of how people think about, influence, and relate to one another,” (p. 4, 2007) covers three critical aspects of students’ and teachers’ daily social experiences. It also adequately covers three core domains of the discipline: social cognition, influence and persuasion, and interpersonal relations.

Although a few teachers may have basic knowledge within a few of these domains, it seems unlikely that most teachers' understandings of the core ideas in these areas would allow them to develop applications for their pedagogy. Prominent educational psychology texts (e.g., Mayer, 2003; Slavin, 2000; Sternberg \& Williams, 2002) rarely have substantive sections on social cognition, influence and persuasion, or intergroup relations. In those instances when these texts offer enough detail to provide prescriptive suggestions to teachers, the research basis for those prescriptions has been called into question in some instances (Dacy, Nihilani, Cestone, \& Robinson, in press). 
Running head: THE SOCIAL SIDE OF SCHOOL

Major state and national tests for teaching certifications (e.g., Massachusetts Tests for Educator Licensure or Praxis) do not require knowledge of these domains for their exams (Educational Testing Service, 2010; Pearson Evaluation Inc., 2010). Likewise, the National Board for Professional Teaching Standards (2010) do not cover these core concepts from social psychology. There is no evidence that teacher professional development opportunities provide this exposure either (Choy, Chen, \& Bugarin, 2006). Thus, infusing certain applications of social psychological ideas into teachers' repertoires seems like a promising approach for bringing important, new ideas into education.

Instead of attempting to catalog the universe of social psychological concepts that offer untapped potential, this article focuses on three examples. These examples illustrate the breadth of social psychology with potential classroom applications (e.g., social cognition, influence and persuasion, and interpersonal relations) while illustrating a range of outcomes (improved pedagogy, bolstered student motivation, and increased student understanding) that these applications might impact. Thus, the examples serve as prototypes that might spark ideas for other novel applications of social psychological principles within classrooms. Although the article’s remains focused on classroom-based applications and outcomes, these principles may be equally helpful in facilitating teachers' understanding important social dynamics elsewhere (e.g., communicating with parents and relationships with administrators).

\section{Reducing Biases and Facilitating Social Perspective Taking to Improve Pedagogy}

Within social cognition, a long tradition of research has examined how people make sense of and perceive each other. Historically, much of this research has focused 
Running head: THE SOCIAL SIDE OF SCHOOL

on biases and mistakes that plague people’s efforts to understand others (Gilbert, 1995; Ross, 1977; Tversky \& Kahneman, 1974). Though little of this research has focused specifically on teachers (see Rosenthal \& Jacobson, 1968 for a well-known exception), presumably they are as susceptible to these biases as anyone else. Recently, this research has been complemented by a renewed interest in the converse of these biases - accurate perceptions of the self and others. Specifically, the proliferation of social perspective taking (SPT) research and its impact on other outcomes has important applications for teachers (e.g., Ames, 2004; Davis, 1996; Hall, Andrzejewski, \& Yopchick, 2009; Ickes, 1997).

Though known by many names (social role-taking, empathic accuracy, everyday mind-reading, interpersonal sensitivity, etc.), the core construct of SPT entails discerning the thoughts and feelings of others with particular attention to how others perceive the situation. According to this formulation, SPT is a complex aptitude, consisting of an ability dimension as well as a motivational dimension —. In other words, for SPT to impact outcomes in the real world, people need to develop both the ability to read the thoughts and feelings of others accurately, and the motivation to engage in SPT frequently.

To the extent that people succumb to common biases that inhibit SPT accuracy less frequently, they should perceive the thoughts, feelings, and motivations of others more accurately. Though numerous biases diminish people’s SPT accuracy, the fundamental attribution error, naïve realism, and confirmation bias seem particularly germane to classroom settings. According to Ross (1977), the fundamental attribution 
Running head: THE SOCIAL SIDE OF SCHOOL

error consists of people's pervasive tendency to explain the social behavior of others by over-weighting the causal role of an individual's personality traits and under-valuing situational causes. Confirmation bias refers to the tendency for people to seek out and value information that corroborates their pet hypothesis, often while ignoring or devaluing contradictory information (Wason, 1960). Naïve realism is the belief that we see objective reality; those that agree with our point of view also see objective reality; but those who disagree must be (a) subject to different (presumably lesser) information, (b) too lazy to process the information fully, or (c) biased (Ross \& Ward, 1996).

Mitigating these biases will help teachers more accurately perceive their students which, in turn, will enhance their pedagogy. To understand how, it is helpful to illustrate how these biases can unfold in classrooms. Among their multiple roles, teachers must monitor students’ academic progress - are students’ grades, homework completion rates, and conceptual understandings improving or not? When a student's rate of progress declines abruptly, teachers need to understand why. In other words, this is a critical moment for teachers to be motivated and accurate in taking the student's perspective if they are to help remediate the situation.

Similarly, it is a moment when the aforementioned biases can conspire to degrade SPT accuracy. If a student fails a test, stops turning in homework, but otherwise seems herself, a teacher might commit the fundamental attribution error by deciding that she is unfocused - that she can perform adequately in school at times but lacks consistency. Developing an equally plausible situational explanation (e.g., the student has a hospitalized relative) takes more imagination and mental effort - teachers simply have 
Running head: THE SOCIAL SIDE OF SCHOOL

less knowledge about students' lives outside of the classroom. With this "inconsistency" explanation in mind, the teacher becomes susceptible to confirmation bias. In other words, instances where the student appears to be distracted will become more salient and more readily remembered than instances where the student appears to be focused on her work. As the teacher's working theory accumulates supporting evidence it becomes increasingly likely that the teacher belief morphs from theory toward "objective reality" and alternative explanations begin to seem less plausible. By contrast, if the teacher were to use a SPT strategy of considering alternative hypotheses (e.g., supplementing the attribution of "unfocused" with two situation-based explanations), past studies indicate that s/he would be less biased and more accurate in perceiving the student (Griffin, Dunning, \& Ross, 1990; Lord, Lepper, \& Preston, 1984). By accurately discerning how students understand their own situation teachers can devise pedagogical interventions to help students recover - an intervention to help a student cope with a hospitalized relative should look much different than one to help an unfocused student.

In addition to improving teachers' SPT as a means to helping them better monitor student progress, SPT can help improve teachers’ pedagogy in other ways. The more accurately teachers infer their students' thought patterns, the more readily they can identify conceptual misunderstandings. For example, describe a science teacher whose SPT particularly focused on anticipating where her chemistry students encountered problems due to their "nonanalytic, sequential way of thinking.” This SPT inference allowed the teacher to tailor her lessons, spend more time on these challenging areas, and provide more examples and 
Running head: THE SOCIAL SIDE OF SCHOOL

supportive materials. While teaching this material, she read students facial expressions to gauge the class’ overall level of comprehension/confusion. Even for proficient perspective takers like this teacher, aspects of SPT ability such as reading facial expressions (Ekman \& Friesen, 2003), and SPT motivation (Davis \& Franzoi, 1991) are malleable and thus can be improved. By more frequently and accurately assessing their students' thoughts in this way, teachers' will present their material in clearer, more effective ways, thereby improving their pedagogy.

Everyone can engage in SPT more frequently and become less biased and more accurate in their perceptions of others. Training teachers to do so should improve their pedagogy in several ways. Improving teachers' SPT should enhance the accuracy of their inferences as they monitor students’ progress. They should be better able to anticipate and prepare for topics that will be conceptually challenging for students - as well as gauge students' developing understandings as the lesson is being taught. Other ways that SPT in particular and social cognition more generally might enhance teachers’ pedagogy are yet to be developed. Scholarship on SPT indicates that it could help improve people's communication (Nickerson, 1999) and conflict resolution (Corcoran \& Mallinckrodt, 2000) - developing applications in these areas seem like other promising avenues for researchers to explore.

\section{Using Cognitive Dissonance to Bolster Student Motivation}

Social psychologists have maintained a lasting fascination with how people influence and persuade one another in social settings. One of the more interesting general conclusions from this work is that the arguments we perceive to be most 
Running head: THE SOCIAL SIDE OF SCHOOL

persuasive tend to come from our own mouths. In particular, the work on cognitive dissonance (Festinger, 1962) has shown that we are adept at self-persuasion and that cognitive dissonance can be a powerful motivating force. Subject to a couple caveats the following rule usually holds true: the more we preach something, the more likely we are to practice it. Unfortunately, few teachers are likely to have been exposed to this work or how might be applied in classrooms (e.g., to help bolster student motivation).

In Festinger’s (1957) original experiment, subjects performed a mind-numbing peg-turning task repeatedly until they were too bored to continue. Next, they were asked to lie to the next participant in the waiting room by explaining how enjoyable the task was. Subjects were then paid $\$ 20, \$ 1$, or $\$ 0$ (depending on their experimental condition) and asked for their true opinion of the task. Those who were paid $\$ 20$ could easily explain lying about a boring task because they were well compensated; those who did it for free could feel good about their altruistic contributions to scientific knowledge. However, the underpaid subjects found themselves in a bind. They had just performed an excruciatingly dull task, lied to an innocent potential subject, and were not even properly compensated for their efforts. Festinger inferred that, to resolve their discomfort, these participants in the $\$ 1$ condition rationalized their discrepant thoughts by convincing themselves that they really did enjoy the task (i.e., practicing what they had already preached). In other words, making this rationalization was easier than entertaining the notion that they were an inconsistent person who lied to others for no particular reason.

Numerous replications and follow-up studies of cognitive dissonance ensued. Cialdini (2009) notes a number of the seemingly absurd lengths people will go to in order 
Running head: THE SOCIAL SIDE OF SCHOOL

to maintain consistency and not threaten their sense of self. He describes how people have agreed to post ugly billboards in their yards, endured harsh hazing rituals, and awaited UFOs for hours - all in an effort to maintain cognitive consistency. From these additional studies, two particularly important caveats have emerged in the theory of cognitive dissonance. First, to experience cognitive dissonance, people must feel that they freely chose to engage in the behavior in question; second, that behavior must have foreseeable negative consequences (Cooper \& Fazio, 1984).

To see how teachers might employ cognitive dissonance to bolster student motivation in a classroom, imagine that a group of eighth-grade teachers wants to address their students’ flagging efforts on homework (or some other behavioral issue). To address this problem, the teachers might implement a variation on a peer tutoring program (Bloom, 1984). By collaborating with a group of fourth grade classrooms, each middle school student would mentor a fourth grade student. In these advisory roles, the eighth graders would be encouraged to stress the importance of thoroughly completing homework assignments, thereby increasing their own experience of cognitive dissonance if they neglected their own homework. Teachers should ensure that the eighth grade students perceived that they freely chose to participate in the tutoring (perhaps by offering an onerous worksheet assignment as an alternative to the tutoring). Leading the eighth graders in a class discussion of the importance of setting a good example for their fourth grade mentees would likely instill a sense of foreseeable negative consequences. Furthermore, voicing their opinions publically to the whole class would likely make them more binding (Cialdini, 2009). Thus, the necessary conditions of perceived free choice 
Running head: THE SOCIAL SIDE OF SCHOOL

and the foreseeability of aversive consequences (Cooper \& Fazio, 1984) could be established.

J. Aronson, Good, and colleagues have attempted interventions with similarities to the one just described using college students as tutors (J. Aronson, Fried, \& Good, 2002; Good, Aronson, \& Inzlicht, 2003). College tutors who espoused to their tutee the view that intelligence is malleable experienced an increase in their own academic performance. Importantly, these positive effects occurred for both the college tutors as well as for the middle school tutees (for grades and standardized test scores respectively). Thus, there is some empirical indication that this type of approach can help students in both tutors' and tutees’ roles.

In addition to motivating students to expend more effort on homework, cognitive dissonance could be used to help students persist on their academic goals for the year. Teachers might facilitate this process by assigning students to write down their goals through a regular classroom assignment. This relatively common exercise could be strengthened by having students then try to convince a peer to adopt at least one of their goals. To strengthen the intervention, teachers could assign students to inform their parents of their list of goals and the reasons why they want to pursue them over the course of the year. Finally, teachers could post each student's goals around the classroom so that they are publicly displayed. As Cialdini (2009) notes, by trying to convince their classmates of the merits of their goals, they will likely convince themselves; by describing their goals and the reasons for their goals to audiences like their parents, they 
Running head: THE SOCIAL SIDE OF SCHOOL

will bolster their commitment to their goals; and by posting the goals in class, the goals will remain salient for students.

\section{Enhancing Student Understanding by Learning about Intergroup Bias}

A third major domain in which social psychologists have substantially enhanced our understanding of the social world, is that of interpersonal and intergroup relations. One of the more intriguing phenomena to emerge from this domain is the research on intergroup bias (Devine, 1995). One obvious classroom application of this work is to guide teachers’ organization of groupwork and to improve intergroup relations between students from different backgrounds or cliques. However, like all the social psychological ideas presented in this article, this concept is flexible in how it might be applied to the classroom. Thus, applications of in-group/out-group research could also help students more deeply understand the content that they are learning.

Much of the research in this area has employed the “minimal group paradigm” in which participants are selected into groups ostensibly based on some superficial criterion (although in reality they are randomly assigned). In a classic example of the effects of grouping individuals into in-groups and out-groups, Sherif and colleagues (Sherif, Harvey, White, Hood, \& Sherif, 1961) invited a group of young boys to summer camp and randomly assigned them to be part of the "Eagles" or "Rattlers” camp. In spite of each group containing boys from the same backgrounds, being the same ages, and having the same interests, discord sparked quickly between the two groups. These groups were "minimal" in that they consisted of nothing more than separate names and separate 
Running head: THE SOCIAL SIDE OF SCHOOL

residences; the resultant conflicts were anything but minimal (including physical conflicts and raids on the opposing group's cabins).

More recently, Galinsky and Moskowitz (2000) created minimal groups by having participants in their study estimate the number of dots on a computer screen. They then randomly assigned participants to be labeled as “overestimators” or "underestimators". Although it is hard to think of a more trivial group designation, individuals from each group favored their own group members over those in the outgroup across ten different traits.

Overall, this research tradition has found that categorizing individuals into these types of meaningless groups has a wide array of effects. In-group members usually allocate more resources to, are more cooperative with, and behave in more prosocial ways towards members of their own group. Furthermore, they evaluate members of their in-group more positively, associate more desirable characteristics with members of the in-group, overestimate their similarities with other in-group members, and overestimate their dissimilarities with out-group members (Devine, 1995). At the core of most theories about why intergroup bias occurs is the idea that people derive self-esteem benefits through associations with in-groups and/or derogations of out-groups (Hewstone, Rubin, \& Willis, 2002).

Knowledge of this concept might help teachers enrich students' understanding of different subjects in a number of ways. Within social studies, students often learn about the treatment of slaves throughout different societies, Hitler's genocide of the Jews leading up to and during World War II, or more modern conflicts e.g., between the Hutus 
Running head: THE SOCIAL SIDE OF SCHOOL

and Tutsis in Rwanda. Teachers who use this lens of intergroup bias to illuminate individual or group behavior in these contexts provide new, meaningful insights into historical events that students do not usually find in history texts. For example, would a threat from a foreign power (i.e., an out-group common to everyone in the U.S.) in 1860 have prevented the civil war in the United States? Knowing that in-group members tend to favor each other, could a stronger super-ordinate in-group identity as “Americans” have prevented the civil war? Are their analogous approaches that could prevent modern countries from devolving into civil wars? Because in-groups and out-groups often permeate schools (Franzoi, Davis, \& Vasquez-Suson, 1994), these types of explorations may be especially effective in making history relevant to students. By examining intergroup relations or other basic social factors that help explain historical events, teachers can more easily connect their subject matter to students own lives. As social psychological research on the self-reference effect indicates, students should better encode and remember new material to the extent that they can relate it to themselves (Symons \& Johnson, 1997).

Beyond social studies classes, English teachers might offer students more nuanced understandings of classics such as The Lord of the Flies or Romeo and Juliet based on the ideas of intergroup bias. Although there is a less direct link to understanding concepts in science and math, teachers might use the concept of intergroup bias to help contextualize some of the current and historical controversies around the content that students now learn. For example, science students might better understand why there was such resistance to accepting the Copernican view of the solar system or 
Running head: THE SOCIAL SIDE OF SCHOOL

mathematics students might better grasp why such hostility exists between those favoring traditional versus reform approaches to teaching math.

\section{How Effective have Social Psychological Interventions been in the Past?}

One way to assess the promise of social psychology for improving education is to examine instances where ideas and concepts from this discipline have been applied to education in the past. Scholars studying achievement motivation (e.g., Midgley, 2002), cooperative groupwork (e.g., Johnson \& Johnson, 2009; Slavin, 1996), attributions about intelligence (Dweck \& Leggett, 1988), and teacher expectancy effects (e.g., Brophy, 1983; Rosenthal, 1991) have applied ideas from social psychology to educational settings. The success of these research programs is, perhaps, unsurprising given that the theories in these domains have obvious applicability to classroom settings. This section

describes two of the more isolated instances when social psychological concepts without clear educational implications have been applied to classrooms; these types of concepts exemplify the unrealized potential of social psychology for learning and teaching.

From the following examples, several benefits of these types of interventions become clear: intervening at the level of social interactions can have multiple desirable outcomes, modest interventions in oft-repeated social processes can produce large effects, and the reinforcing patterns in many social phenomena may allow for brief interventions that change interaction patterns to have lasting effects.

\section{Example \#1: The Jigsaw Classroom}

One of the most famous and successful examples of social psychology in the classroom is that of Elliot Aronson's (1978, 2000a) jigsaw technique. The jigsaw 
Running head: THE SOCIAL SIDE OF SCHOOL

classroom arose out of a need to improve relations between African-American, Hispanic, and White students in post-desegregation Texas. Although variations exist, the basic pattern of a jigsaw classroom is as follows. Initially, students are assigned to work on a complex task in a small group which is heterogeneous with regard to race (or some other category). The task is sufficiently complex and requires enough different skills and/or knowledge, that no one group-member can complete the task alone. Instead, members of this initial group must divide up and work with other classmates in “expert” groups. In these second groups, students work with specialized resources or develop new skills. After developing their unique expertise, they return to their original group to work on the problem by synthesizing the new knowledge and skills that each group-member has brought back from his or her respective expert group.

Cooperative groupwork can take many different forms, but several principles and related research findings from social psychology illustrate why the jigsaw technique is particularly effective. First, research on prejudice indicates that mere contact between members of different racial groups is insufficient to ameliorate the ill-will between them; other conditions must be in place (Pettigrew, 1998). Second, people tend to engage in social loafing when working in groups unless individual accountability mechanisms are in place (Latane, Williams, \& Harkins, 1979). Third, according to the scarcity principle, people tend to place a higher value on scarce information as compared to information that everyone can access (Cialdini, 2009).

Each of these principles is embedded within the jigsaw activity. First, the groups are structured for much more than mere contact. Students’ groups are cooperative and 
Running head: THE SOCIAL SIDE OF SCHOOL

interdependent rather than competitive and independent; students enter into these groups as equal status participants; they are striving to solve a common problem; the teacher supports their interactions; and students have the potential to become friends. A cooperative context, equal status participation, common goals, authority support, and “friendship potential” are exactly the conditions that Pettigrew (1998) identifies as facilitating prejudice reduction during intergroup contact. Second, students are held accountable by their original groups for bringing back information from their expert groups. Because the group relies on the knowledge and skills that each and every student brings back from their unique expert group, social loafing cannot occur without harmful repercussions for the entire group. Third, because the information that students bring back from their expert groups is scarce - nobody else in the group has the specialized knowledge from the expert group - the other members of the group are more likely to value it.

The results of the jigsaw classroom are impressive. As compared to control classrooms, students in classrooms that implemented the jigsaw technique regularly experienced a wide range of beneficial outcomes including gains in self-esteem, interpersonal attraction towards their group-mates, and empathy between students of different races. Perhaps most importantly, the academic achievement of minority students improved without any cost to the performance of majority group students (E. Aronson \& Bridgeman, 1979). Subsequent to the jigsaw’s initial success, these results have been consistently replicated in classrooms all across the country (E. Aronson, 1999). 
Running head: THE SOCIAL SIDE OF SCHOOL

\section{Example \#2: Reducing Stereotype Threat}

More recently, Cohen, Garcia, Apfel, and Master (2006) showed dramatic reductions in the Black-White achievement gap through an intervention designed to enhance Black students’ sense of self-integrity thereby providing a buffer against any sense of stereotype threat that they might feel in the classroom. In other words, the authors argued that by bolstering their sense of self-worth, students might feel less threatened by classroom situations that could otherwise seem threatening and stressful. They conducted a brief intervention early in the semester which consisted of having students complete what was ostensibly a classroom assignment. For the assignment students had to indicate which of a list of values were most important to them, write a brief paragraph about why the selected values were important to them (in the treatment group) or to somebody else (in the control group), and rate how much they agreed with statements about the values (e.g., "I care about these values” for the treatment group, and “Some people care about these values” for the control group). When the researchers examined students' final semester grades, they found that the Black students in the treatment group experienced gains of .26 grade points in the first study and .34 in the replication as compared to the Black students in the control group. Remarkably, they found that these effects carried over to other classes (i.e., students' overall grade-pointaverage) as well. Given that the initial intervention took about 15 minutes and was so simple, these substantial increases in grade-point-average seem almost too good to be true. 
Running head: THE SOCIAL SIDE OF SCHOOL

The authors explain how this intervention impacts student achievement by drawing on three assumptions based on past social psychological research related to stereotype threat. First, students are motivated to maintain their self-integrity. Second, negative group characterizations can threaten students' self-integrity because students’ self-integrity is partially based on their group affiliations. For example, Black students who feel that race is a part of their self-concept might feel personally threatened by negative stereotypes of Blacks. Third, when these threats are sufficiently severe, students’ performance will suffer. To address this causal chain of events, the authors intervened by helping students reaffirm their self-integrity. In other words, by helping remind students of their values, the intervention helped buffer students' self-integrity against the stress of negative race-based stereotypes. In the absence of threats to selfintegrity, the students in the treatment group had more cognitive resources available to focus on learning. They note that this affirmation process also likely interrupts a “recursive cycle” of threats to their self-integrity and "could have long-term effects” (p. 1309). This study provides a dramatic example of how a small intervention at the level of students' social cognitions can result in a large outcome in actual achievement over an extended period of time.

To summarize, these two programs of research illustrate how both substantial, multifaceted interventions and abbreviated, narrowly focused interventions rooted in social psychological principles can produce multiple, dramatic, and lasting beneficial outcomes for students. Given the success of these past applications of social psychology and the unrealized potential of other social psychological concepts (beyond the three 
Running head: THE SOCIAL SIDE OF SCHOOL

examples previously described), the challenge becomes thinking of avenues for infusing social psychology into teachers’ repertoires.

\section{How might the Potential Contributions of Social Psychology be Realized?}

In thinking about how this infusion of novel social psychological principles might happen, the role of teacher educators, particularly educational psychologists, seems pivotal. First, social psychological principles need to be adapted into actual classroom practices. Scholars working within teacher education are uniquely positioned to perform this translation function. They have the background and training in social science research to understand and evaluate social psychological research, and they have a rich understanding of the context in which teachers work. Second, the newly developed classroom practices need to be evaluated. Because concepts and empirical findings do not always generalize from the laboratory (the context for many social psychology studies) to the classroom, new research needs to assess which applications of social psychological principles transfer. The aforementioned research background and contextual knowledge of teacher educators perfectly positions them to design studies that can examine the efficacy of new applications of social psychological principles.

Given that teacher educators seem particularly well-positioned to help develop applications of social psychology and disseminate them to teachers, how should they approach this task? Although it might seem obvious to advocate for a class on Applied Social Psychology in the Classroom for pre-service teachers, it seems unlikely that many teacher preparation programs would adopt such a course. Most programs are already over-saturated with requirements. A more promising approach to placing these ideas in 
Running head: THE SOCIAL SIDE OF SCHOOL

the hands of pre-service teachers might be to use part of existing courses to focus on some of these ideas. Admittedly, space and time for new ideas are tight in these courses too. However, social psychological principles can provide an efficient way to clarify preservice teachers' understanding of topics that are being covered anyway. For example, a conversation about Piagetian disequilibrium could easily incorporate the broader idea of cognitive dissonance and its powerful motivational effects in other aspects of the classroom. Discussions of diversity in classrooms are likely to happen in many courses naturally, so introducing the concept of intergroup bias and research from the minimal group paradigm provides an efficient explanation of why teachers often find it challenging to integrate students from different backgrounds or cliques. Furthermore, because the introduction of these concepts would center on social aspects of classroom dynamics pre-service teachers will have had some prior experience with them (e.g., most everyone has experienced cognitive dissonance or been an out-group member at some point). To the extent that teacher educators can show pre-service teachers how these concepts relate to their own experiences, these students are more likely to process the new ideas quickly and remember them better (see Symons \& Johnson, 1997 for a review of the self-reference effect).

Although promising, this approach is only a partial solution at best. There are far more worthy ideas from social psychology than might be squeezed into pre-service coursework. Furthermore this approach would not help the myriad of teachers already practicing. To augment the first approach, teacher educators can incorporate social psychological concepts into professional development workshops. First-year teachers are 
Running head: THE SOCIAL SIDE OF SCHOOL

particularly likely to be interested in classroom management, while more experienced teachers prioritize pedagogical skills (Coalition for Psychology in Schools and Education, August, 2006). Fortunately, many of the ideas from social psychology may address multiple goals such as these simultaneously. For example, a professional development session that helps teachers improve their social perspective taking should help them to better anticipate where students may struggle to understand content and determine which explanations are likely to work best. Likewise, these same skills should also improve their personal relationships with students - an important focus given that better teacher-student relationships are associated with a host of valuable student outcomes ranging from improved academic achievement, engagement, and persistence to graduation (Juvonen, 2007).

One problem endemic to much of teacher professional development is that teachers may be reticent to change their classroom practices until they experience evidence of a new program’s efficacy (Guskey, 2002). Fortunately, as the Cohen et al. (2006) study suggests, even modest interventions may produce large and/or lasting effects. Thus, leaders of professional development may be more likely to get compliance from teachers by trying out small interventions, showing their effectiveness, and then earning more latitude to implement larger interventions at a later date. In other words, these small but powerful interventions may be an effective means for getting a "foot-inthe-door" (Cialdini, 2009).

Infusing novel social psychological content into pre-service coursework and professional development workshops will provide a useful starting place for expanding 
Running head: THE SOCIAL SIDE OF SCHOOL

the role of social psychology within education. However, in their roles as researchers and evaluators of effective classroom practices, teacher educators are particularly well-suited for a third critical role. As teacher educators study the efficacy of applying social psychological principles in their own research agendas, they can disseminate their findings in practitioner journals in addition to outlets that serve academic audiences. By simultaneously informing colleagues and practitioners as to which interventions demonstrate the most potential, scholars can create audiences across two populations.

Through these multiple approaches the odds are much greater that teachers will receive more exposure to the untapped potential of many of these social psychological concepts. Furthermore, as has been well-documented by social psychologists, to the extent that some educators receive multiple exposures to these ideas, they are likely to view them more favorably (Zajonc, 2001).

\section{Concluding Thoughts}

Social interactions lie at the heart of classroom learning. As a result, thoughtful, new applications of social psychological principles may have multiple, large, lasting benefits for teachers and students. These applications are needed in schools now more than ever. The current focus on standardized testing and high stakes accountability requires teachers to develop an exceptionally effective, efficient skill set. Typically, teachers must cover a tremendous breadth of content while keeping students sufficiently motivated to retain the information; simultaneously, if they want to prepare students for the type of integrative thinking that will be required in many $21^{\text {st }}$ century jobs (Levy \& Murnane, 2004), they will also need to help students develop complex understandings of 
Running head: THE SOCIAL SIDE OF SCHOOL

this content from different perspectives. Although it would be naïve to think that teaching teachers new social psychological concepts and how to apply them will be a panacea, these principles do provide powerful tools to improve teachers’ pedagogy, bolster student motivation, and enrich students’ understanding of multiple content areas. Furthermore, depriving teachers of the tools to understand the social dynamics of their classrooms carry a host of costs that schools simply cannot afford. 
Running head: THE SOCIAL SIDE OF SCHOOL

\section{References}

Ames, D. (2004). Strategies for social inference: A similarity contingency model of projection and stereotyping in attribute prevalence estimates. Journal of Personality and Social Psychology, 87(5), 573-585.

Aronson, E. (1978). The jigsaw classroom. Beverly Hills, CA: Sage.

Aronson, E. (1999). The social animal (8th ed.). New York: Worth Publishers: W.H. Freeman.

Aronson, E. (2000a). Jigsaw classroom Retrieved June 30, 2002, from http://www.jigsaw.org/

Aronson, E. (2000b). Nobody left to hate: Teaching compassion after Columbine. New York: W.H. Freeman.

Aronson, E., \& Bridgeman, D. (1979). Jigsaw groups and the desegregated classroom: In pursuit of common goals. Personality and Social Psychology Bulletin, 5(4), 438446.

Aronson, J., Fried, C. B., \& Good, C. (2002). Reducing the effects of stereotype threat on African American college students by shaping theories of intelligence. Journal of Experimental Social Psychology, 38(2), 113-125.

Bloom, B. S. (1984). The 2 sigma problem: The search for methods of group instruction as effective as one-to-one tutoring. Educational Researcher, 13(6), 4-16.

Brophy, J. E. (1983). Research on the self-fulfilling prophecy and teacher expectations. Journal of Educational Psychology, 75(5), 631-661. 
Running head: THE SOCIAL SIDE OF SCHOOL

Choy, S. P., Chen, X., \& Bugarin, R. (2006). Teacher Professional Development in 19992000: What Teachers, Principals, and District Staff Report (NCES 2006-305). Washington, DC: National Center for Education Statistics.

Cialdini, R. B. (2009). Influence: Science and practice (5th ed.). Boston, MA: Pearson. Coalition for Psychology in Schools and Education (August, 2006). Report on the Teacher Needs Survey. Washington, D.C: American Psychological Association, Center for Psychology in Schools and Education.

Cohen, G. L., Garcia, J., Apfel, N., \& Master, A. (2006). Reducing the racial achievement gap: A social-psychological intervention. Science, 313(5791), 13071310.

Cooper, J., \& Fazio, R. H. (1984). A new look at dissonance theory. In L. Berkowitz (Ed.), Advances in experimental social psychology (Vol. 17, pp. 229-266): Academic Press.

Corcoran, K. O., \& Mallinckrodt, B. (2000). Adult attachment, self-efficacy, perspective taking, and conflict resolution. Journal of Counseling \& Development, 78(4), 473483.

Dacy, B. S., Nihilani, P., Cestone, C., \& Robinson, D. H. (in press). (Lack of) support for prescriptive statements in teacher education textbooks. Journal of Educational Research.

Davis, M. H. (1996). Empathy: A social psychological approach. Boulder: Westview Press. 
Running head: THE SOCIAL SIDE OF SCHOOL

Davis, M. H., \& Franzoi, S. L. (1991). Stability and change in adolescent selfconsciousness and empathy. Journal of Research in Personality, 25(1), 70-87.

Devine, P. (1995). Prejudice and out-group perception. In A. Tesser (Ed.), Advanced social psychology (pp. 466-524). New York: McGraw-Hill.

Dweck, C. S., \& Leggett, E. L. (1988). A social-cognitive approach to motivation and personality. Psychological Review, 95(2), 256-273.

Educational Testing Service (2010). The Praxis Series Retrieved April 12, 2010, from http://www.ets.org/portal/site/ets/menuitem.fab2360b1645a1de9b3a0779f175150 9/?vgnextoid=48c05ee3d74f4010VgnVCM10000022f95190RCRD

Ekman, P., \& Friesen, W. V. (2003). Unmasking the face: A guide to recognizing emotions from facial clues. Cambridge: Malor.

Ferguson, R. F. (2003). Teachers' perceptions and expectations and the Black-White test score gap. Urban Education, 38(4), 460-507.

Festinger, L. (1957). A theory of cognitive dissonance. Evanston, Ill.: Row Peterson.

Festinger, L. (1962). Cognitive dissonance. Scientific American, 207(4), 93-107.

Fine, M. (1991). Framing dropouts: Notes on the politics of an urban public high school. Albany, N.Y.: State University of New York Press.

Fiske, S. T., \& Taylor, S. E. (1991). Social cognition (2nd ed.). New York, NY, England: McGraw-Hill Book Company.

Franzoi, S. L., Davis, M. H., \& Vasquez-Suson, K. A. (1994). Two social worlds: Social correlates and stability of adolescent status groups. Journal of Personality \& Social Psychology, 67(3), 462-473. 
Running head: THE SOCIAL SIDE OF SCHOOL

Galinsky, A. D., \& Moskowitz, G. B. (2000). Perspective-taking: Decreasing stereotype expression, stereotype accessibility, and in-group favoritism. Journal of Personality and Social Psychology, 78(4), 708-724.

Gehlbach, H. (2004). A new perspective on perspective taking: A multidimensional approach to conceptualizing an aptitude. Educational Psychology Review, 16(3), 207-234.

Gehlbach, H., \& Brinkworth, M. E. (manuscript under review). The social perspective taking process: Strategies and sources of evidence in taking another's perspective.

Gilbert, D. T. (1995). Attribution and interpersonal perception. In A. Tesser (Ed.), Advanced social psychology (pp. 98-147). New York: McGraw-Hill.

Good, C., Aronson, J., \& Inzlicht, M. (2003). Improving adolescents' standardized test performance: An intervention to reduce the effects of stereotype threat. Journal of Applied Developmental Psychology, 24(6), 645-662.

Goodenow, C. (1992). Strengthening the links between educational psychology and the study of social contexts. Educational Psychologist, 27(2), 177-196.

Griffin, D. W., Dunning, D., \& Ross, L. (1990). The role of construal processes in overconfident predictions about the self and others. Journal of Personality and Social Psychology, 59(6), 1128-1139.

Guskey, T. R. (2002). Professional development and teacher change. Teachers and Teaching: Theory and Practice, 8(3), 381-391. 
Running head: THE SOCIAL SIDE OF SCHOOL

Hall, J. A., Andrzejewski, S. A., \& Yopchick, J. E. (2009). Psychosocial correlates of interpersonal sensitivity: A meta-analysis. Journal of Nonverbal Behavior, 33(3), 149-180.

Hewstone, M., Rubin, M., \& Willis, H. (2002). Intergroup bias. Annual Review of Psychology, 53(1), 575-604.

Ickes, W. J. (Ed.). (1997). Empathic accuracy. New York: The Guilford Press.

Johnson, D. W., \& Johnson, R. T. (2009). An educational psychology success story: Social interdependence theory and cooperative learning. Educational Researcher, 38(5), 365-379.

Juvonen, J. (2006). Sense of belonging, social bonds, and school functioning. In P. A. Alexander \& P. H. Winne (Eds.), Handbook of educational psychology. (pp. 655674). Mahwah, NJ, US: Lawrence Erlbaum Associates Publishers.

Juvonen, J. (2007). Reforming middle schools: Focus on continuity, social connectedness, and engagement. Educational Psychologist, 42(4), 197-208.

Latane, B., Williams, K., \& Harkins, S. (1979). Many hands make light the work: The causes and consequences of social loafing. Journal of Personality and Social Psychology, 37(6), 822-832.

Levy, F., \& Murnane, R. J. (2004). The new division of labor: How computers are creating the next job market. Princeton, N.J.: Princeton University Press.

Lord, C. G., Lepper, M. R., \& Preston, E. (1984). Considering the opposite: A corrective strategy for social judgment. Journal of Personality and Social Psychology, 47(6), 1231-1243. 
Running head: THE SOCIAL SIDE OF SCHOOL

Mayer, R. E. (2003). Learning and instruction. Upper Saddle River, N.J.: Merrill.

Midgley, C. (2002). Goals, goal structures, and patterns of adaptive learning Mahwah, NJ: L. Erlbaum Associates.

Myers, D. G. (2007). Exploring social psychology (4th ed.). New York: McGraw-Hill. National Board for Professional Teaching Standards (2010). Certificate Areas, from http://www.nbpts.org/

National Center for Educational Statistics (2009). What are the dropout rates of high school students? Retrieved November 30, 2009, from http://nces.ed.gov/fastfacts/display.asp?id=16.

Nickerson, R. S. (1999). How we know--and sometimes misjudge--what others know: Imputing one's own knowledge to others. Psychological Bulletin, 125(6), 737759.

Olweus, D., Fry, D. P., Bjoerkqvist, K., \& et al. (1997). Tackling peer victimization with a school-based intervention program Cultural variation in conflict resolution: Alternatives to violence. Mahwah: Lawrence Erlbaum Associates Inc.

Pearson Evaluation Inc. (2010). Massachusetts Tests for Educator Licensure Retrieved April 12, 2010, from http://www.mtel.nesinc.com/index.asp

Pettigrew, T. F. (1998). Intergroup contact theory. Annual Review of Psychology, 49, 6585.

Reynolds, C. R., Skiba, R. J., Graham, S., Sheras, P., Conoley, J. C., \& Garcia-Vazquez, E. (2008). Are zero tolerance policies effective in the schools?: An evidentiary review and recommendations. American Psychologist, 63(9), 852-862. 
Running head: THE SOCIAL SIDE OF SCHOOL

Rosenthal, R. (1991). Teacher expectancy effects: A brief update 25 years after the pygmalion experiment. Journal of Research in Education, 1(1), 3-12.

Rosenthal, R., \& Jacobson, L. (1968). Pygmalion in the classroom; teacher expectation and pupils' intellectual development. New York: Holt Rinehart and Winston.

Ross, L. (1977). The intuitive psychologist and his shortcomings: Distortions in the attribution process. In L. Berkowitz (Ed.), Advances in experimental social psychology (Vol. 10, pp. 173-220). Orlando, FL: Academic Press.

Ross, L., \& Ward, A. (1996). Naive realism in everyday life: Implications for social conflict and misunderstanding. In E. S. Reed \& E. Turiel (Eds.), Values and knowledge (pp. 103-135). Mahwah: Lawrence Erlbaum Associates Inc.

Sherif, M., Harvey, O. J., White, B. J., Hood, W., \& Sherif, C. (1961). Intergroup conflict and cooperation; the Robbers Cave experiment. Norman: University of Oklahoma. Institute of Intergroup Relations.

Slavin, R. E. (1996). Research on cooperative learning and achievement: What we know, what we need to know. Contemporary Educational Psychology, 21(1), 43-69.

Slavin, R. E. (2000). Educational Psychology: Theory and practice (6th ed.). Boston: Allyn \& Bacon.

Sternberg, R. J., \& Williams, W. M. (2002). Educational psychology. Boston: Allyn and Bacon.

Symons, C. S., \& Johnson, B. T. (1997). The self-reference effect in memory: A metaanalysis. Psychological Bulletin, 121(3), 371-394. 
Running head: THE SOCIAL SIDE OF SCHOOL

Tversky, A., \& Kahneman, D. (1974). Judgment under uncertainty: Heuristics and biases. Science, 185(4157), 1124-1131.

Wason, P. C. (1960). On the failure to eliminate hypotheses in a conceptual task. The Quarterly Journal of Experimental Psychology, 12, 129-140.

Zajonc, R. B. (2001). Mere exposure: A gateway to the subliminal. Current Directions in Psychological Science, 10(6), 224-228. 
Running head: THE SOCIAL SIDE OF SCHOOL

\section{Acknowledgements:}

The author is grateful to Maureen Brinkworth, Jere Brophy, Kristy Cooper, and Hahrie Han whose incisive comments improved this manuscript tremendously. 